\title{
Effect of ethylene-diamine-tetra-acetic acid (dipotassium salt) and heparin on the estimation of packed cell volume
}

\author{
C. A. PENNOCK AND K. W. JONES \\ From the Department of Haematology, Gibson Laboratories, Radcliffe Infirmary, \\ Oxford
}

SYNOPSIS The effect of varying concentrations of ethylene-diamine-tetra-acetic acid (E.D.T.A. (dipotassium salt) and heparin on the estimation of packed cell volume has been studied using $\%$ microhaematocrit method. Varying concentrations of E.D.T.A. can produce serious errors estimation of packed cell volume (P.C.V.) and reliable results are only obtained within the range of 1 to $2 \mathrm{mg} . / \mathrm{ml}$. Heparin is a more suitable anticoagulant for this investigation as varying the co centration has little effect. Storage with either anticoagulant at suitable concentrations for 24 houक्षs at room temperature has little influence on the results.

The estimation of the packed cell volume (P.C.V.) is regarded as a reliable investigation in the diagnosis of anaemia, and errors in the estimation of mean corpuscular haemoglobin concentration (M.C.H.C.) are thought to be due more often to errors in the estimation of haemoglobin than of the P.C.V. (Biggs and MacMillan, 1948; Jones, 1961; Stengle, Strumia, Liddy, and Brecher, 1965).

The introduction of an improved high-speed micro-haematocrit method (Strumia, Sample, and Hart, 1954) and the use of the salts of ethylenediamine-tetra-acetic acid (E.D.T.A.) as anticoagulants (Hadley and Larson, 1953) has resulted in a large number of laboratories using E.D.T.A. as the anticoagulant for routine blood counts and the determination of the P.C.V.

The high speed micro-haematocrit consistently yields P.C.V.s $1-3 \%$ lower than conventional methods and this affects the calculated M.C.H.C. (Strumia et al., 1954; Stengle et al., 1965). This effect is due to the smaller amount of trapped plasma when using this method and more complete packing of cells (Garby and Vuille, 1961).

In routine investigations, M.C.H.C.s within the normal range 32-36\% (Dacie and Lewis, 1963) are occasionally found in patients with proven irondeficiency anaemia and some normochromic patients apparently have an abnormally high M.C.H.C. These obvious errors are disturbing and may be due to increased anticoagulant concentration, as specimen bottles are often returned to this laboratory contai ing less than the recommended amount of blood.

Ethylene-diamine-tetra-acetic acid is known $\bar{\Phi}$ cause distortion and shrinkage of red cells aod to affect the estimation of P.C.V. by conventional

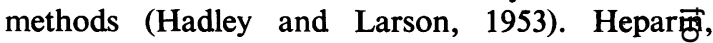
however, causes little alteration in corpuscular size when used as an anticoagulant (Dacie and Lewis, 1963). It is the purpose of this paper to examine the effect of storage in and concentration of both these anticoagulants on the estimation of P.C.V. by a high speed micro-haematocrit method.

\section{MATERIAL AND METHODS}

All the P.C.V.s were determined on samples which had been mixed mechanically for at least five minutes. The estimations were carried out in heat-sealed capillafify tubes $75 \mathrm{~mm}$. long (Hawksley \& Sons, Ltd.) and cen证fuged for five minutes at 10,000 r.p.m. $(12,000 \times g)$ irna Hawksley microhaematocrit centrifuge. The tubes were read in a Hawksley micro-haematocrit reader to nearest $0.5 \%$. Each sample was centrifuged in duplicâfe and read by each of two observers and the result expressed as the mean of the four readings.

In addition, the P.C.V. of a single sample of blood measured 48 times using the dipotassium salt of E.D.T at a concentration of $1.6 \mathrm{mg}$. $/ \mathrm{ml}$. blood. The length $:$ of the column of blood was measured as well as the packed cell volume. An experiment was done in which blo $\mathrm{d}$ from eight patients was distributed in 1, 3, and 5 ml. amounts into bottles containing $8 \mathrm{mg}$. E.D.T.A. and $5 \mathrm{ml}$. amount into 100 units of heparin, the concentrations being $8,2 \cdot 7$, and $1.6 \mathrm{mg}$. E.D.T.A. per millilitre bloరd 
and 20 units heparin per millilitre of blood respectively. Packed cell volumes were estimated at once and after 24 hours at room temperature.

Venous blood was collected from a further 12 patients and a constant volume of blood $(2 \mathrm{ml}$.) was added to different amounts of E.D.T.A. and heparin. The amounts of E.D.T.A. used gave final concentrations of 16, 8, 4, 2, $1 \cdot 6,1 \cdot 2,0 \cdot 8$, and $0.4 \mathrm{mg}$. per ml. of blood and the heparin amounts gave 5,10 , and 50 units per $\mathrm{ml}$. of blood. The P.C.V.s were estimated at once and again after 24 hours at room temperature. The haemoglobin of each patient was estimated by a haemoglobin-cyanide method and the M.C.H.C. calculated according to the conventional formula.

Venepuncture was performed on three patients and two plain microhaematocrit tubes were filled directly from the syringe and the P.C.V. determined immediately before coagulation had taken place. Other samples from the same syringe were put into E.D.T.A. $(1.6 \mathrm{mg} . / \mathrm{ml}$.), heparin (20 units $/ \mathrm{ml}$.), and a portion defibrinated. The P.C.V. was determined in duplicate on each of these specimens.

\section{RESULTS}

Forty-eight estimations on the one sample gave a mean value of $44.6 \%$ with a standard deviation of $0.6 \%$. Differences in the length of the column had no detectable effect on the packed cell volume.

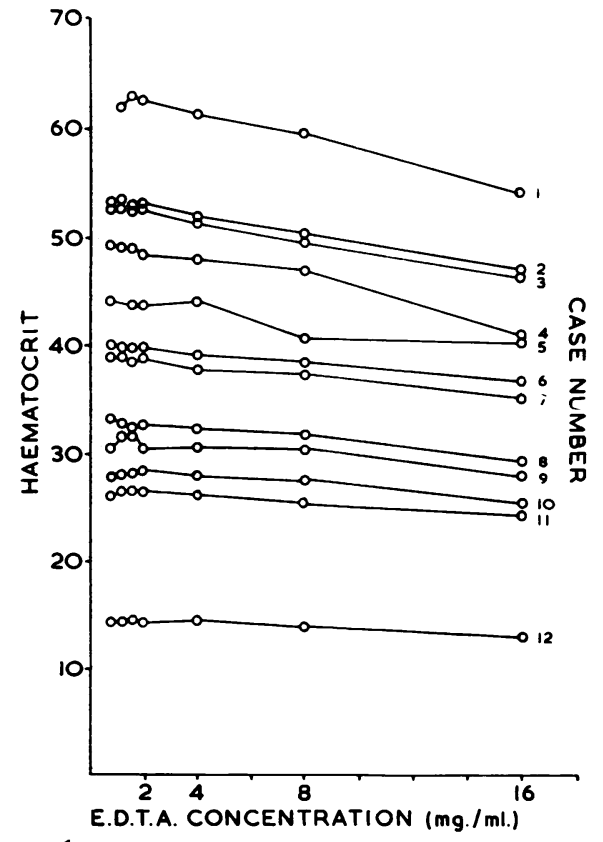

FIG. 1.
Changing concentrations of E.D.T.A. resulted in changes in the packed cell volume. All the samples with only $0.4 \mathrm{mg}$. E.D.T.A./ml. clotted. A reduction in P.C.V. was observed in all samples where the concentration of E.D.T.A. exceeded $2 \mathrm{mg} . / \mathrm{ml}$. of blood (Fig. 1). The patients' P.C.V.s ranged from $14.5 \%$ to $62.6 \%$ and, although the effect appears to be more marked in patients with higher P.C.V.s, in all cases they are reduced at $16 \mathrm{mg}$./ml. by 6 to $16 \%$ of their P.C.V. at 1 to $2 \mathrm{mg} . / \mathrm{ml}$., the latter being taken as $100 \%$.

The effect of these reductions on the calculated M.C.H.C. is shown, for nine of the 12 patients, in Figure 2. (Three of the results are omitted in the interests of clarity as their results closely parallel three of those shown.) Six of the 12 patients had a lower than normal M.C.H.C. at the lower concentrations of E.D.T.A. and a normal M.C.H.C. at the higher concentrations.

There was no marked difference between the samples containing 1.2 or $1.6 \mathrm{mg}$. E.D.T.A. per millilitre blood and those containing heparin in 20 of 50 units per millilitre blood concentrations. The results are shown in Table I together with those obtained after storage for 24 hours at room temperature which appeared to have little effect. The results are summarized in Table II.

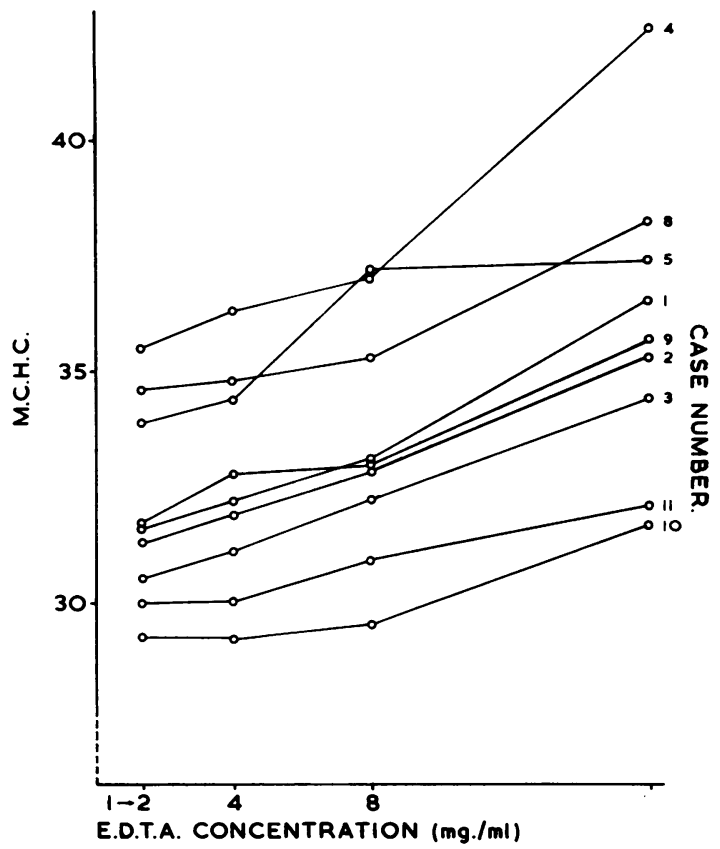

FIG. 2.

FIG. 1. The effect of E.D.T.A. concentration on microhaematocrit values in 12 patients.

FIG. 2. The effect of E.D.T.A. concentration on calculated M.C.H.C. in nine of the 12 patients siown in Figure 1. 
TABLE I

COMPARISON BETWEEN P.C.V. USING HEPARIN AND E.D.T.A. AS ANTICOAGULANT

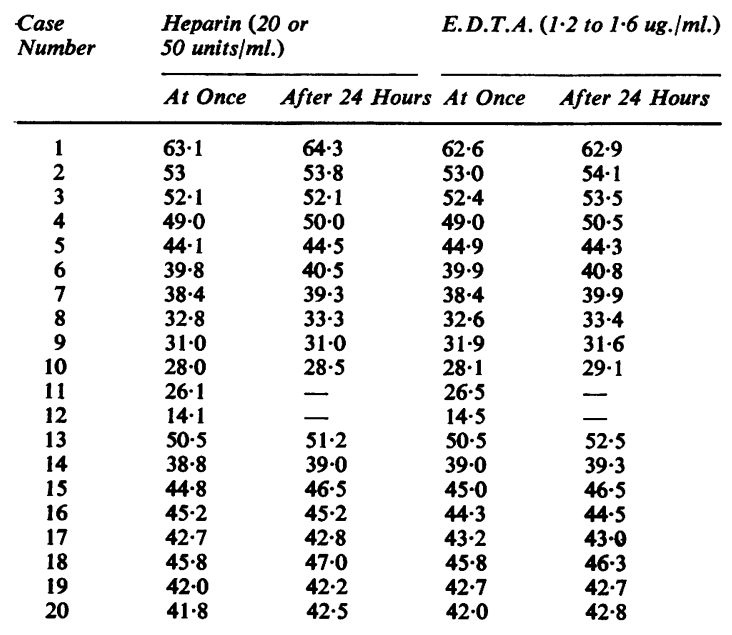

\section{TABLE II}

AVERAGE DIFFERENCES IN P.C.V. FROM DATA IN TABLE I

Fresh E.D.T.A. $>$ fresh heparin by $0.16 \%$ $24 \mathrm{hr}$.-E.D.T.A. $>24 \mathrm{hr}$. heparin by $0 \cdot 15 \%$ 24 hr. E.D.T.A. > fresh E.D.T.A. by $0.70 \%$ $24 \mathrm{hr}$. heparin $>$ fresh heparin by $0.60 \%$

The small study on the effect on differing concentrations of heparin is shown in Table III. Results of P.C.V.s when using $10 \mathrm{u}$. $/ \mathrm{ml}$. show good agreement with those obtained at $50 \mathrm{u}$. $/ \mathrm{ml}$. Results with $5 \mathrm{u} . / \mathrm{ml}$. are inconsistent, two of the specimens showing small clots on close inspection.

\section{TABLE III}

EFFECT OF DIFFERENT CONCENTRATIONS OF HEPARIN ON P.C.V.

\begin{tabular}{lll} 
Heparin & \\
\cline { 2 - 3 } 5 units $/ \mathrm{ml}$. & 10 units $/ \mathrm{ml}$. & 50 units $/ \mathrm{ml}$. \\
\hline $30 \cdot 5^{1}$ & & $32 \cdot 7$ \\
$43 \cdot 6$ & & $44 \cdot 1$ \\
$27 \cdot 1^{1}$ & & $28 \cdot 0$ \\
$52 \cdot 5$ & & $52 \cdot 1$ \\
& $53 \cdot 3$ & $53 \cdot 0$ \\
& $38 \cdot 5$ & $38 \cdot 4$ \\
& $39 \cdot 6$ & $39 \cdot 8$ \\
& $49 \cdot 3$ & $39 \cdot 0$ \\
& $14 \cdot 1$ & $14 \cdot 1$
\end{tabular}

'Small clots present

There was no appreciable difference between the P.C.V.s of the blood taken directly into plain haematocrit tubes, into E.D.T.A. (1.6 mg./ml.), into heparin $(20 \mathrm{u} . / \mathrm{ml}$.$) , or as defibrinated blood \stackrel{0}{\stackrel{0}{\circ}}$ (Table IV).

TABLE IV

P.C.V.S OF THREE PATIENTS COLLECTED IN FOUR DIFFERENT WAYS

\begin{tabular}{|c|c|c|c|c|c|c|c|c|}
\hline \multirow{2}{*}{$\begin{array}{c}\text { Patient } \\
21 \\
22 \\
23\end{array}$} & \multicolumn{2}{|c|}{$\begin{array}{l}\text { Whole } \\
\text { Blood }\end{array}$} & \multicolumn{2}{|c|}{$\begin{array}{l}\text { Defibrinated } \\
\text { Blood }\end{array}$} & \multicolumn{2}{|c|}{$\begin{array}{l}\text { E.D.T.A. } \\
(I .6 \mathrm{mg} . / \mathrm{ml} .)\end{array}$} & \multicolumn{2}{|c|}{$\begin{array}{l}\text { Heparin } \\
(20 \mu / m l .)\end{array}$} \\
\hline & $\begin{array}{l}42 \cdot 5 \\
47.0 \\
43.0\end{array}$ & $\begin{array}{l}43.0 \\
47.0 \\
42.5\end{array}$ & $\begin{array}{l}42.5 \\
46.5 \\
42.0\end{array}$ & $\begin{array}{l}42.5 \\
47.0 \\
42.0\end{array}$ & $\begin{array}{l}42 \cdot 5 \\
47 \cdot 0 \\
42 \cdot 5\end{array}$ & $\begin{array}{l}42 \cdot 5 \\
46 \cdot 5 \\
42 \cdot 5\end{array}$ & $\begin{array}{l}42.5 \\
46.5 \\
42.5\end{array}$ & $\begin{array}{l}42.5 \\
46.5 \\
42.5\end{array}$ \\
\hline
\end{tabular}

The measurement of packed cell volume is $\overrightarrow{0}$ dependent on the size and density of the cell, the force applied, the time of spinning, difference in $\vec{\rho}$ density of cell and plasma medium and viscosity of the medium (Ponder and Saslow, 1930; Chaplin and Mollison, 1952). 'When the anticoagulant, force time of spin, and haematocrit tube are standardized the method gives a consistent estimate of the volumes of packed cells' (Leeson and Reeve, 1951).

The micro-haematocrit is a reliable method of estimating packed cell volume with complete packing in a short time even at low speeds (Strumia et al. 1954; Kaldor, 1953), contrary to the suggestion of Ponder (1948) that sedimentation would be retarde $\bar{\phi}$ in a narrow tube.

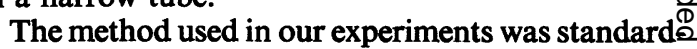
ized in each particular except for the anticoagulan $\vec{S}$ and its concentration. Differences in the length o $B$ the blood column had no measurable effect.

Hadley and Larson (1953) found a reduction in P.C.V. with a tenfold increase in E.D.T.A. using two human volunteers, but the method is not given: Our results extend this observation to 12 patients an to the micro-haematocrit method and show that the effect is progressive outside the small optimum concentration (1-2 $\mathrm{mg} . / \mathrm{ml}$. blood). We believe that these changes are due to red cell shrinkage and distortion in shape as this change is easily observet in stained films of these samples. Whether this change is due to osmosis or a 'toxic' effect on the ref cell envelope has not been determined.

The P.C.V. of blood in an E.D.T.A. concentration of 1 to $2 \mathrm{mg} . / \mathrm{ml}$. shows good agreement with heparinized blood, defibrinated blood, and whole blood spun immediately in which the cells are les likely to be distorted. Below this concentration the blood tends to clot, and above the red cells are reduced in volume. At this optimal concentration of E.D.T.A., the effect of storage for 24 hours at roon temperature is the same as in the heparinized samples?

Our own experience has shown that using $\mathbb{Q}$ specimen bottle designed for $5 \mathrm{ml}$. blood $(8 \mathrm{mg}$ 
E.D.T.A.) samples are often sent in volumes much less than $5 \mathrm{ml}$. and the resulting concentrations of E.D.T.A. being outside the optimum range, produce large errors in the P.C.V. and the M.C.H.C.

A five-fold increase in heparin concentration had no effect on the P.C.V. and therefore heparin $(10-50 \mathrm{u} . / \mathrm{ml}$. blood) would appear to be a superior anticoagulant to E.D.T.A. for the accurate measurement of haemoglobin, P.C.V., and M.C.H.C. and should be used for the purposes of standardization. Ethylene-diamine-tetra-acetic acid, is, however, a more useful anticoagulant when the other cellular constituents (white cells and platelets) have to be examined, and is therefore more suitable for routine diagnostic use. It is important to stress that the concentration of the latter must be within the critical range if packed cell volume is to be estimated with acceptable accuracy.

We wish to thank Dr. A. A. Sharp for his helpful advice and criticism and Dr. T. M. Parry for the photographs.

\section{REFERENCES}

Biggs, R., and MacMillan, R. L. (1948). J. clin. Path., 1, 269.

Chaplin, H., Jr., and Mollison, P. L. (1952). Blood, 7, 1227.

Dacie, J. V., and Lewis, S. M. (1963). In Practical Haematology, 3rd ed., pp. 5, 12. Churchill, London.

Garby, L., and Vuille, J. C. (1961). Scand. J. clin. Lab. Invest., 13, 642. Hadley, G. G., and Larson, N. L. (1953). Amer. J. clin. Path., 23, 613.

Jones, R. F. (1961). J. clin. Path., 14, 198.

Kaldor, I. (1953). Med. J. Aust., 11, 476.

Leeson, D., and Reeve, E. B. (1951). J. Physiol. (Lond.), 115, 129.

Ponder, E. (1948). In Haemolysis and Related Phenomena. p. 57. Grune and Stratton Inc. N.Y.

— and Saslow, G. (1930). J. Physiol., (Lond.), 70, 18.

Stengle, J. M., Strumia, M. M., Liddy, T. J., and Brecher, G. (1965). In Standardisation, Documentation and Normal Values in Haematology. Bibl. haemat. (Basel)., Fasc., 21, p. 4.

Strumia, M. M., Sample, A. B., and Hart, E. D. (1954). Amer. J. clin. Path., 24, 1016.

\section{ADDENDUM}

Since this work was submitted for publication similar findings reported by Lampasso (1965) have come to our attention.

\section{REFERENCE}

Lampasso, J.A. (1965). Amer. J. clin. Path., 44, 109. 